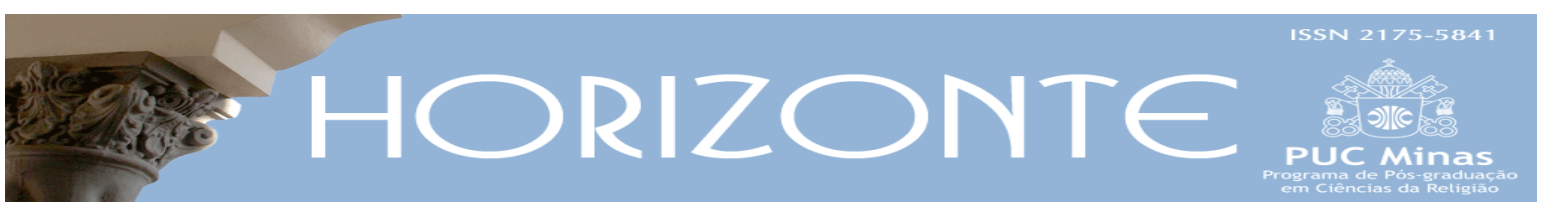

Temática Livre - Artigo original

@

DOI - 10.5752/P.2175-5841.2019v17n53p1091

\title{
A Teologia na árvore das áreas de conhecimento
}

\author{
Theology in the tree of academic disciplines
}

César Andrade Alves*

\begin{abstract}
Resumo
O advento da Ciência moderna e seu método expôs o método teológico a novas exigências. O objetivo do artigo é justificar metodologicamente a presença da Teologia entre as disciplinas científicas. A metodologia é a da pesquisa bibliográfica. $O$ artigo evidencia os elementos em comum entre o método científico e o teológico e suas peculiaridades, com ênfase nas premissas de ambos. Essa abordagem é inédita na literatura metodológica. Isso permite, por um lado, evidenciar os elementos em comum. Primeiro, o ato de fé. Em Ciência faz-se um ato de fé naquelas premissas do método, pois para elas não há demonstração cabal, nem estão elas abertas à falseabilidade. Tal abordagem é também inédita. São evidenciadas oito dessas premissas do método científico. Uma das premissas é a da natureza pura, cuja origem é examinada. Essa premissa é pela primeira vez trazida à reflexão sistemática sobre o método científico. Segundo, o seguimento da sequência de cinco passos metodológicos. Por outro lado, o artigo evidencia os elementos distintivos entre os dois métodos. A adesão a uma confissão religiosa é a principal diferença epistemológica entre a Teologia e a Ciência, em particular as Ciências da Religião. Para essas isso traz consequência.
\end{abstract}

Palavras-chave: Método científico; Método teológico; Ciência; Ciências da Religião; Epistemologia.

\begin{abstract}
The advent of modern Science has subjected Theology to new demands. Our scope is to justify methodologically the presence of Theology among scientific disciplines. Bibliographical research method is used. We demonstrate the features both methods have in common, and the particular characteristics of each. The postulates of each method are emphasized. Such approach is unprecedented. On the one hand, the common features they have in common can be demonstrated. First, the act of faith. In Science an act of faith is made in those methodological postulates, for they do not have full evidence, neither they are subject to falsifiability. Such approach is also unprecedented. Eight of such postulates are pointed out. One of these postulates is pure nature, which origin is particularly discussed. It's the first time this postulate is systematically discussed in the field of scientific methodology. Second, the sequence of five methodological steps. On the other hand, this paper highlights the distinctive features of each method. Adherence to a religious confession is the main epistemological difference between Theology and modern Science, in particular Sciences of Religion. That fact brings consequence to the latter.
\end{abstract}

Keywords: Scientific method; Theological method; Science; Sciences of Religion; Epistemology

Artigo submetido em 09 de abril de 2018 e aprovado em 02 de maio de 2019.

* Doutor em Teologia pela Pontifícia Università Gregoriana. Professor da FAJE. País de origem: Brasil. E-mail: cesar.alves@faculdadejesuita.edu.br 


\section{Introdução}

Um grande tesouro da cena acadêmica nas últimas décadas tem sido o avigoramento dos estudos sobre os temas da religião. Não raro tais estudos, feitos por diversos ramos do saber, confluem para instâncias nas quais compõem um conjunto. No Brasil sobressaem de modo especial os congressos da Associação Nacional de Pós-graduação e Pesquisa em Teologia e Ciências da Religião (ANPTECRE) e da Sociedade de Teologia e Ciências da Religião (SOTER). A não poucos, tais estudos sobre os temas da religião têm propiciado indagações a respeito do método. Uma coisa é estudar a religião através das disciplinas do subconjunto das Ciências da Religião. Outra coisa é trabalhar os temas religiosos a partir da Teologia, que compõe outro subconjunto. O objeto de pesquisa dos dois subconjuntos apresenta uma substância em comum, e as duas óticas se enriquecem mutuamente, mas "não se deve deixar na sombra o que lhes é constitutivo, tanto do ponto de vista do objeto material, quanto do ponto de vista do objeto formal. [... Pode-se] abrir o debate sobre as respectivas epistemes, conscientes da importância capital para a inter-relação entre estas áreas do saber" (EDITORIAL, 2007, p. 160). Indagações dos teólogos sobre seu método têm sido frequentes nas últimas décadas, buscando adquirir mais clareza sobre o que constitui a sua perspectiva específica (LONERGAN, 2012; BAENA, 2007; ELLACURÍA, 2000).

Nosso foco aqui não é o método teológico latino-americano, embora este seja de grande relevância. O foco é examinar o método teológico num horizonte mais vasto, que permita reconhecer, como produto da mesma metodologia, obras teológicas de outros continentes e épocas.

Tomamos como desafio o comentário de Walter Kasper, que manifestou uma determinada urgência na questão metodológica. Sua observação mantém grande atualidade, não obstante ter sido escrita há meio século:

A reflexão sobre os fundamentos metodológicos faz parte das tarefas prioritárias da Teologia pós-conciliar. Tal reflexão metodológica se encontra hoje inevitavelmente exposta a uma exigência de precisão metodológica proveniente da Ciência moderna. A nossa época se 
caracteriza, na sua compreensão de realidade e verdade, pela Ciência e pela técnica. A essência da Ciência é seu método, isto é, o caminho planejado, ponderado, sempre criticamente seguro rumo a um bem determinado objetivo cognitivo. [...] Essa moderna consciência metodológica mudou não só a Teologia, mas todas as Ciências Humanas, para uma situação supercrítica. (KASPER, 1967, p. 12)1.

Recorrendo à metodologia da pesquisa bibliográfica, neste artigo serão delineados, num primeiro momento, alguns elementos do método teológico e os passos do método científico. Trata-se do estado da questão. Num segundo momento, traremos também à luz seus respectivos pressupostos. Inexiste na literatura um estudo que, ao mesmo tempo, os delineie, confronte as premissas de ambos e demonstre as consequências que seguem. Serão explicitados: 1) o ato de fé nas premissas, ato esse que faz parte da natureza mesma do método científico (com ênfase na premissa da existência de uma natureza pura, numa reflexão inédita na literatura metodológica), e 2) a cidadania que os passos do método científico têm dentro do método teológico na sua forma atual. É legítima, portanto, a inclusão da Teologia na árvore das áreas de conhecimento, composta pelas diversas áreas do saber acadêmico, tema que desenvolveremos na última parte do artigo. Nesta, completaremos o delineamento do método teológico e de suas premissas, à luz das reflexões anteriores, e serão também evidenciadas as semelhanças (bem como as diferenças) entre o método teológico e o científico que justificam aquela inclusão.

As fontes e documentos teológicos utilizados estarão dentro da Teologia católica, campo no qual se desenvolve o presente trabalho. Exceção será feita ao livro de Wolfhart Pannenberg (1973). Vários dos elementos aqui mostrados serão desenvolvidos mais extensamente numa obra que há de vir a ser publicada pelas Edições Loyola ${ }^{2}$.

\footnotetext{
${ }^{1}$ "Eine methodische Grundlagenbesinnung gehört zu den vordringlichsten nach konziliaren Aufgaben der Theologie. Eine solche Methodenbesinnung sieht sich heute unausweichlich dem Anspruch methodischer Exaktheit ausgesetzt, wie er von der modernen Wissenschaft ausgeht. Unser Zeitalter ist in seinem Verständnis von Wirklichkeit und Wahrheit durch Wissenschaft und Technik bestimmt. Das Wesen dieser Wissenschaft ist die Methode, das heißt der planmäßige, reflektierte, dauernd kritisch abgesicherte Weg zu einem ganz bestimmten Erkenntnisziel [...]. Dieses moderne Methodenbewußtsein hat nicht nur die Theologie, sondern alle Geisteswissenschaften in eine äußerst kritische Lage versetzt".

${ }^{2} \mathrm{O}$ artigo foi originalmente enviado em maio de 2018. O livro apareceu em 2019 com o título Método teológico e Ciência.
} 
Esta reflexão não se situa nas categorias do binômio natural-sobrenatural. A revelação judaico-cristã possui uma sólida premissa, de que tudo na criação só pode vir a ser, e continuar existindo, devido à graça divina. Por isso, teologicamente não utilizamos a distinção entre ato de fé teologal e ato de fé natural. Todo e qualquer ato de fé só pode vir a ser o que é por trazer, antes e embaixo de si, o sustentáculo da graça de Deus como condição de possibilidade para existir.

\section{Começando a delinear o método teológico}

Sobre a história do método da Teologia, alguns autores mais significativos são Johannes Beumer (1972), Guido Pozzo (1994) e Clodovis Boff (2012). O estudo das estruturas que, no passado, configuraram o exercício da Teologia é relevante para esse mesmo exercício no presente.

\section{1 Época Patrística}

A Época Patrística representa como que “o momento do 'nascimento' da Teologia" (POZZO, 1994, p. 607). A literatura patrística é extremamente diversa. Além da esfera greco-latina, abrange também autores em língua siríaca, copta, armênia, georgiana e árabe. Mesmo com tanta diversidade, é possível encontrar ali elementos de um método. O fulcro em que os autores patrísticos esteavam suas reflexões era a revelação em Israel culminada em Cristo. É à luz de 1 Cor 3,11 ("ninguém pode colocar outro alicerce diferente do que já está colocado: Cristo”) que se desenvolve o método teológico, para o qual "o evento Cristo transmitido é e permanece o fundamento, juntamente com a experiência espiritual, que dele brota, [feita] pela Igreja, mas [...] esse mesmo fundamento solicita o prosseguimento da edificação em cima dele" (BEUMER, 1972, p. 17)3. Tornaram-se famosas as duas frases de S. Agostinho que resumiam a importância do alicerce e do "prosseguimento da edificação" mediante a fé e a razão: "crede ut intellegas" e "intellege ut credas", "creia para que possa compreender" e "compreenda para que possa crer”.

\footnotetext{
3 “Das überlieferte Christusereignis zusammen mit der daraus entspringenden Geisterfahrung der Kirche ist und bleibt das Fundament. Sobald aber [...] verlangt dieses Fundament selbst danach, daß auf inm weitergebaut wird".
} 
Na Teologia da Época Patrística, o método se assinala pelo reconhecimento de uma apostolicidade expressa pelo termo parádosis (Tradição). Tal termo designa uma realidade viva e ativa mantida em sucessão com os apóstolos. Uma fórmula da época é "parádosis katá diadokén" (literalmente, "Tradição conforme sucessão" (PIE-NINOT, 1994, p. 86). Encontrado já nos textos de Ireneu de Lyon, esse princípio "se tornou uma lei aceita pela Patrística" (PIE-NINOT, 1994, p. 86). A apostolicidade expressa como parádosis ou Tradição era a experiência de comunhão com aquele que permanece realmente vivo e atuante no tempo atual da Igreja, Cristo. No entender patrístico, a parádosis ou Tradição é também autocomunicação de Deus. É revelação salvífica viva que dá de novo a descobrir o que já foi revelado originalmente no cume da revelação que é Cristo.

Na Época Patrística, outro elemento do método é o reconhecimento que determinados escritos - a Sagrada Escritura - são registro indispensável da revelação acontecida em Israel e em Cristo. São os únicos escritos nos quais se reconhece, além da autoria humana, a autoria divina, e por isso compõem instância fundamental.

Na Época Patrística, o método se assinala também pela dinâmica de, num contexto de diversidade, clarificar as coisas resistindo ao que falsifica o fundamento, a revelação salvífica culminada em Cristo. Não vale tudo. Há coisas que adulteram aquela revelação, e tais falsificações devem ser deixadas de lado (BEUMER, 1972, p. 18).

À medida que aquela unidade das diversas Igrejas locais produzia decisões mediante sínodos e concílios, essas se tornavam também instâncias de manifestação da parádosis ou Tradição. Notável relevância era também atribuída aos ensinamentos do sucessor do apóstolo Pedro como epískopos de Roma. Algo análogo acontecia com as reflexões das gerações anteriores de teólogos.

Enfim, na Teologia da Época Patrística o método se caracteriza também por ser reflexão conduzida com os recursos intelectuais então existentes (BEUMER, 1972, p. 17-18). Não raro os autores patrísticos fazem a mensagem original da 
revelação salvífica cristã penetrar num âmbito cultural que havia surgido independentemente do cristianismo. Empregam as categorias de um mundo filosófico já existente, e o fazem a partir dos elementos da revelação cristã (POZZO, 1994, p. 607).

\section{2 Época Escolástica}

$\mathrm{Na}$ Época Escolástica a Teologia manteve, por um lado, os elementos metodológicos da Patrística: estear as reflexões na revelação culminada em Cristo, e aprofundar os dados da fé tirados da Sagrada Escritura, da Sagrada Tradição, dos ensinamentos dos concílios e do sucessor de Pedro, e da vida da Igreja (POZZO, 1994, p. 608). As antigas expressões de S. Agostinho - "crede ut intellegas" e "intellege ut credas" - continuam a sintetizar a reflexão teológica. No século XI, S. Anselmo de Cantuária sintetiza essas ideias no Proslogion através das expressões "credo, ut intellegam" e "fides quaerens intellectum": "creio, para compreender" e "uma fé que procura a inteligência".

Por outro lado, aos elementos metodológicos herdados da Época Patrística foi acrescentado mais um: o instrumental filosófico aristotélico (BEUMER, 1972, p. 75; POZZO, 1994, p. 608). Em especial, adota-se o paradigma do conceito aristotélico de Ciência. Ciência seriamente falando - a Ciência primeira -, é ali a Metafísica, que vai além do sensorial e atinge o conhecimento das verdades imutáveis.

Um traço marcante da Teologia Escolástica é a dupla de conceitos natural e sobrenatural. Esses conceitos pressupõem uma concepção da realidade diferenciada em planos. Por um lado, o plano do natural é o da criação, do ser humano e de sua iniciativa. Por outro lado, o plano do sobrenatural é o de Deus, do que é incriado, das coisas que só acontecem devido à gratuita iniciativa divina, como a revelação. O termo sobrenatural está "em paralelo preciso com o termo metafísica (depois de, atrás de, para além de, e, neste sentido: acima da natureza)" 
(NEUFELD, 1994, p. 909). No século XIII, a dupla de conceitos foi impulsionada por S. Tomás de Aquino, e marcaria a feição da Teologia nos séculos seguintes.

\subsection{Considerações}

Começando a delinear o método teológico encontramos já uma evidência: 1) quem faz a reflexão não está numa posição neutra no que diz respeito à confissão religiosa. Um salto de fé acompanha o raciocínio. Metodologicamente, em Teologia ato de fé e ato de raciocinar estão constantemente imbricados: "creia para que possa compreender" e "compreenda para que possa crer". No nosso caso trata-se da confissão cristã. A Teologia também pode ser feita em outras confissões religiosas como, por exemplo, Teologia islâmica, Teologia judaica ou Teologia umbandista. Outra evidência: 2) quem faz a reflexão teológica não começa da estaca zero. Há muita coisa antes dele que precisa ser conhecida. A expressão clássica para se referir a isso é auditus fidei, escuta da fé: ouvir as diversas e determinadas instâncias anteriores. Uma terceira evidência: 3) é necessário raciocinar, "prosseguir a edificação em cima dele [o fundamento, o evento Cristo]" (BEUMER, 1972, p. 17$)^{4}$. A expressão clássica para se referir a isso é intellectus fidei, raciocínio sobre a fé, valendo-se de instrumentais conceituais de seu tempo.

\section{Delineamento do método científico}

Não muito tempo depois da Escolástica, a argúcia humana foi colocando em evidência uma estratégia para gerar conhecimentos: o método científico. A literatura sobre a história da Ciência e seu método é generosa, e referimos aqui apenas exemplos (HEGENBERG, 1976; HENRY, 1998; ACHINSTEIN, 2004). Na nossa consideração sobre o método científico, o consideraremos primeiramente num resumo de seus passos, algo frequente na literatura. Depois traremos à luz suas premissas, ou axiomas. Essa temática importante é raras vezes abordada (AAAS, 1990, p. 2; GAUCH, 2012, p. 73-95).

\footnotetext{
4 "auf ihm [dem Fundament, dem Christusereignis] weitergebaut wird".
} 


\subsection{Passos ou movimentos do método científico}

Resumos substanciais das etapas do método científico já são oferecidos na literatura acadêmica (MEDAWAR, 1979; LEITE, 2008; RAMPAZZO, 2009; KÖCHE, 2012). Nas diversas apresentações do método, a substância deste é sempre a mesma, mas o número dos passos ou movimentos difere de autor para autor em virtude de as etapas serem diferentemente condensadas ou desmembradas. Apresentamos aqui uma síntese da estratégia, ou método científico, por meio de cinco passos ou movimentos:

1. O ponto de partida é ter um assunto sobre o qual se quer obter conhecimento confiável. Desse assunto faz-se então uma caracterização geral: define-se a questão em estudo, tentando explicitar os elementos de sentido da questão; reúnem-se as evidências relevantes sobre o assunto mediante o levantamento das explicações já dadas por outras pessoas; examina-se o objeto em consideração e fazem-se observações e medições. É fundamental procurar as explicações já dadas anteriormente, um domínio satisfatório do patrimônio anterior de conhecimento. Mas só conhecimento não basta.

2. Imaginação e criatividade estão no centro do segundo passo ou movimento. Sobre aquele assunto do qual se quer obter conhecimento confiável formulam-se hipóteses que visem explicar a questão. Richard Feynman - um dos mais importantes cientistas do século XX e prêmio Nobel de Física em 1965 - resumiu: "o que precisamos é imaginação, mas imaginação numa tremenda camisa de força" (FEYNMAN, 1992, p. 171)5. Acrescentar ao conhecimento prévio do passo 1, a hipótese ou suposição deste passo 2, não é coisa de pouca monta. A imaginação e a criatividade que geram hipóteses estão na linha de frente da grandeza da Ciência. A formulação de hipóteses sobre os elementos de uma questão é uma arte (MEDAWAR, 1979, p. 84-85; FEYNMAN, 1992, p. 162).

5 "What we need is imagination, but imagination in a terrible strait-jacket". 
3. A imaginação e a criatividade prosseguem operantes neste passo ou movimento 3. Trata-se agora de elaborar raciocínios que levam a deduções. O conjunto de hipótese (feita no passo 2) e previsão (estabelecida agora no passo 3) é geralmente algo nunca antes observado. As previsões feitas a partir das hipóteses são cruciais porque se o quarto passo, em seguida, mostrar que as previsões não se realizam, então a hipótese formulada no passo 2 é simplesmente falsa. Mesmo uma Ciência que trabalhe com pesquisa bibliográfica pode realizar previsões. Por exemplo, um historiador pode formular previsões sobre documentos que ainda terão que ser encontrados, prevendo que o que neles se encontrará sobre determinados fatos coincidirá com o que está escrito nos documentos já conhecidos (FEYNMAN, 1992, p. 114).

4. Chegou a hora de validar, ou invalidar, a conjectura e as previsões imaginadas nos passos 2 e 3. Compostas até aqui por raciocínios lógicos que levam a deduções, as previsões estabelecidas no passo 3 são enfim testadas. Algumas Ciências demandam experimentos com a natureza. Outras estudam o ser humano, que por razões éticas nunca deverá ser manuseado como um objeto. Há aquelas que têm como objeto coisas produzidas pelo ser humano, ou fenômenos humanos. Outras são formais, abstratas. Sendo todas Ciências e seguindo o método científico, por um lado cada uma delas terá idiossincrasias epistemológicas para validação das hipóteses. Tais idiossincrasias são "particularidades lógico-metodológicas secundárias" (COSTA, 1999, p. 23). No seu conjunto, "a Ciência empírica, em determinado sentido, é uma, sobretudo devido à sua dimensão lógico-metodológica geral" (COSTA, 1999, p. 23). Em todas elas, visa-se comprovar as consequências que foram previstas a partir da hipótese feita, de modo a demonstrá-las ou refutá-las. Se tal processo de validação mostrar que as previsões oriundas da hipótese acontecem, então a hipótese está no bom caminho. Se as previsões feitas a partir da conjectura não se verificarem, então a hipótese é falsa. Toda a Ciência gira em torno desse duplo princípio. Se hipótese for validada, contudo meramente essa comprovação individual ainda não basta. 
5. A divulgação e comprovação por outrem estão no centro do quinto passo. Se um êxito qualquer conseguido no passo 4 ficar só para quem o obteve, ainda não se tornou conhecimento confiável. "É este o requisito fundamental do conhecimento científico: é necessário que seja aceito pelos demais cientistas" (VOLPATO, 2007, p. 29). A publicação do estudo possibilita que o conhecimento seja repetido e comprovado em tempos e espaços diferentes. É desse modo que um determinado conhecimento se integra ao patrimônio daquela Ciência específica.

\subsection{Premissas do método científico}

2.2.1 Premissas filosóficas (AAAS, 1990, p. 2; GAUCH, 2012, p. 88)

Newton C. A. da Costa (1999, p. 55) fala de cinco "normas ou princípios que iluminam a marcha da Ciência”. Trata-se de princípios epistemológicos que são válidos, mas para os quais "não há demonstração cabal e lícita, dedutiva ou indutiva” (COSTA, 1999, p. 57). Quatro deles são:

1. A possibilidade do conhecimento científico.

2. O caráter deste como intercâmbio de experiência e pensamento.

3. O caráter lógico e experimental dos critérios de justificação.

4. A utilização de sistemas de categorias ou conceitos.

O quinto corresponde ao primeiro dos quatro outros axiomas ou premissas abaixo indicados, que complementam e se somam aos quatro anteriores.

5. Realismo. Há "um universo de coisas e fatos que existem independentemente de nós. Alcançamos, sem dúvida, certas estruturas que são, pelo menos em parte, reais" (COSTA, 1999, p. 55). Para a Ciência moderna, existe uma realidade objetiva externa que independe do sujeito compreendedor. Nesse sentido, 
"no entanto, o realismo científico é um realismo mitigado. [...] Os objetos físicos estão fora de nós, se bem que os reconstruímos conceitualmente" (COSTA, 1999, p. 50).

6. Existência de leis da natureza. As coisas fundamentais da realidade objetiva externa não funcionam caprichosamente, mas seguem padrões chamados de leis. Tais "leis da natureza [...] existem independentemente das mentes que tentam compreendê-las" (ARMSTRONG, 1999, p. 7) ${ }^{6}$, ou seja, seguem também o princípio do realismo.

7. Universalidade ou constância das leis da natureza. "A melhor característica da lei física é a sua universalidade" (FEYNMAN, 1992, p. 87)². As leis da natureza são constantes no tempo e no espaço.

\subsubsection{Premissa teológica}

8. Natureza pura. Os textos de metodologia científica nunca mencionam esta quarta premissa. Por natureza compreende-se aqui toda a realidade do cosmo. "Natureza pura" significa toda essa realidade como uma "natureza completa, consistente, suficiente, independente por ela mesma em relação a qualquer 'ordem' superior" (DE LUBAC, 1946, p. 174) ${ }^{8}$.

Tal expressão faz originalmente parte de uma tríade de conceitos estreitamente vinculados: natural, sobrenatural e natureza pura. Na Teologia católica, a distinção entre natural e sobrenatural foi lançada em grande circulação no século XIII por Tomás de Aquino. Só mais tarde, no século XVI, é que o conceito de natureza pura foi introduzido em Teologia, agora por Tommaso Gaetano. O conceito de natureza pura "foi introduzido como que de modo enviesado, sem jamais ter sido objeto de uma discussão apropriada" (DE LUBAC, 1946, p. 129)9. Em Teologia, desde o século XVI o conceito de natureza pura se manteve

\footnotetext{
6 "laws of nature [...] exist independently of the minds which attempt to grasp them".

7 "The best characteristic of physical law is its universality".

8 "[cette] nature comme complète, consistante, suffisante, indépendante par elle-même à l'égard de tout 'ordre' supérieur".

9 “[Elle] s'y introduit comme de biais, sans jamais faire l'objet d'une discussion en règle".
} 
meramente como hipótese irreal, mas capaz de ser considerada. O intuito era o de articular mais facilmente a graça divina (âmbito sobrenatural) com uma hipotética atividade puramente humana (âmbito natural). No século XVII o conceito de natureza pura já estava consolidado em Teologia, e seus principais defensores eram os renomados jesuítas de Paris e de Leuwen (DE LUBAC, 1946, p. 162).

Aquilo que, por um lado, era em Teologia uma hipótese irreal, por outro lado teve consequências não pequenas para o pensamento de quem estava fora da Teologia, mas vivendo no mesmo ambiente de cristandade. Já a partir do século XVI o conceito de natureza pura habituou gerações de estudiosos brilhantes a pensar tal hipótese não mais como irreal, mas como plausível. A premissa da natureza pura, que leva a considerar o cosmo como uma "natureza completa, consistente, suficiente, independente por ela mesma em relação a qualquer 'ordem' superior", é distintiva do método científico levado a efeito no continente europeu a partir do século XVII. Pensadores brilhantes transferem, para o interior da natureza, o motivo da existência e do funcionamento do cosmo, privando-o do seu horizonte de transcendência. Verifica-se uma fermentação cultural na qual se pensa a natureza do ser humano como independente de qualquer ordem superior ou transcendente. Em 1651 era publicado o Leviatã de Thomas Hobbes, cujo primeiro capítulo intitulado De homine (Sobre o ser humano) o considera de modo exclusivamente materialista. Outras obras influentes desenvolvidas em base ao axioma epistemológico da natureza pura viriam à luz no século XVIII. Neste ponto, mais relevantes que o famoso Discurso sobre a origem de Jean-Jacques Rousseau em 1755 (que negava a existência do ser humano no puro estado de natureza, reputado como utopia),são as obras de dois outros autores. Em 1758 foi publicado o livro Do Espírito, de Claude Helvétius, e em 1770 saiu do prelo o Sistema da natureza, de Paul-Henri Thiry, conhecido como Barão de Holbach. Aparece ali claramente manifestada a independência do âmbito da natureza em relação a qualquer transcendência: "os seres que são considerados como acima da natureza ou dela distintos serão sempre quimeras, das quais nunca será possível constituir ideias verdadeiras" (HOLBACH, 2010, p. 31). 
Foi em tal contexto onde ainda se vivia a cristandade, no qual por um lado em Teologia o conceito de natureza pura estava consolidado (como hipótese irreal) que, não por coincidência, se alçou por outro lado a pujante onda da revolução científica do Ocidente. O conceito de natureza pura foi passando de conceito hipotético e irreal em Teologia para axioma epistemológico da atividade dos cientistas. A premissa de uma natureza pura se consolidaria como distintiva da nova etapa da metodologia científica. Metodologicamente, a partir dessa época considera-se por premissa que qualquer ordem superior à natureza não influencia os resultados, e que a Ciência prescinde de Deus. "Qualquer entidade que, por definição, existe além das leis naturais, está além da esfera da Ciência" (GLEISER, 2011). Metodologicamente, o ato religioso de fé que o cientista pode ter se torna, por premissa, irrelevante. Os resultados devem ser os mesmos, caso outro cientista (cujo ato de fé fosse dado em outra religião, ou então fosse um ato de fé na inexistência de Deus) faça a mesma pesquisa em condições objetivas semelhantes. Durante o exercício do trabalho científico, o ato religioso de fé fica como que entre parênteses, sem interferir nos resultados.

A consolidação do conceito de natureza pura tem estreita relação com o reinado, em Ciência, do paradigma mecanicista de mundo. Neste "a natureza não pode mais ser concebida como a manifestação de um princípio vivo, mas como um sistema de matéria em movimento regido por leis" (JAPIASSU, 2007, p. 182). Mediante essa ótica, "a natureza deve ser explicada por ela mesma. A fé, a graça e a revelação deixam de desempenhar o papel de obstáculos epistemológicos" (JAPIASSU, 2007, p. 179). O paradigma mecanicista consistia numa nova imagem de cosmo "como uma grande máquina, um grande e preciso relógio mecânico, estabelecendo-se a visão de um universo ordenado e previsível" (BORGATTI, 2012, p. 37).

Ao se ter como base tal paradigma mecanicista, também o ser humano é visto como máquina. Já no século XVIII, nos referidos livros Do Espírito, de Claude Helvétius, e Sistema da natureza, do Barão de Holbach, o ser humano é concebido apenas como um complexo mecanismo. "Por falta de conhecer a energia da máquina 
humana, [os homens] supuseram [...] que ela era animada por um espírito" (HOLBACH, 2010, p. 138). Noções como espírito e alma são deixadas de lado porque vistas como invencionice. "Inventou-se a palavra alma para exprimir fracamente as energias de nossa vida [...]. A alma, que significa nossa memória, nossa razão, nossas paixões, não é, pois, ela mesma mais do que uma palavra" (HELVÉTIUS, 1988, p. 289-290). Já naquela época, o que controla o ser humano é considerado unicamente como um elemento da natureza, o cérebro:

Aqueles que distinguiram a alma do corpo nada mais parecem ter feito do que distinguir seu cérebro de si mesmo. Com efeito, o cérebro é o centro comum aonde vêm dar e se confundir todos os nervos espalhados por todas as partes do corpo humano. É com a ajuda desse órgão interno que se realizam todas as operações que são atribuídas à alma (HOLBACH, 2010, p. 136-137).

A palavra liberdade não ostenta aí consistência verdadeira: "quando se aplica esse termo liberdade à vontade [...], não se pode vincular nenhuma ideia nítida a esse termo liberdade. [...] Livre é, então, apenas um sinônimo de esclarecido" (HELVÉTIUS, 1988, p. 158). O ser humano é considerado como desprovido de liberdade. Mais recentemente, essa já antiga concepção de ser humano como um complexo mecanismo tem sido retomada com novos termos e conceitos, tais como neurônios, genes e DNA, por autores como Richard Dawkins (1976) e Galen Strawson (1994).

\subsection{Considerações}

Primeiramente, tecemos considerações sobre os ricos resultados a que o método científico chega. Esse método assenta-se numa intenção particular. "O conceito nuclear da teoria da Ciência é o de verdade. Nas várias Ciências procura-se algum tipo de verdade" (COSTA, 1999, p. 22). O resultado obtido tem sido a produção de conhecimentos confiáveis sobre a realidade, distintos do conhecimento que é senso comum, facilmente enganável. Contudo, "a Ciência não alcança a verdade" (POPPER, 1975, p. 305). A história da Ciência mostra continuamente que, quando é concedida validação metodologicamente científica à teoria ou leis, posteriormente podem surgir novos fatos que mostrem que essas são 
falsas. O emprego do método continua aberto para que novos resultados invalidem aquela teoria ou lei e atestem sua falsidade. O método científico é estruturalmente aberto a uma permanente crítica dos conhecimentos confiáveis e à falseabilidade deles. O resultado obtido pelo método científico é quase verdade, isto é, aproximadamente verdadeiro. Tenta-se obter resultados cada vez mais próximos da realidade tal como ela é. As teorias são como redes que são lançadas para capturar a realidade e explicá-la (POPPER, 1975, p. 41-44; 82-98).

Uma segunda consideração sobre os resultados é a evidência de que quem os obtém mediante o método científico não começa da estaca zero. Há um patrimônio de conhecimento já obtido anteriormente. Metodologicamente, o pesquisador precisa ouvir o que já foi conseguido antes dele.

Uma terceira consideração sobre os resultados, os conhecimentos confiáveis obtidos, é que sua validade não depende da confissão religiosa de quem os obtém. A fé religiosa do pesquisador permanecerá inativa, como que situada entre parênteses.

Uma quarta consideração sobre os resultados é o caráter de crença verdadeira que assinala os resultados ou conhecimentos confiáveis obtidos mediante o método científico. Nem toda crença é verdadeira. Uma crença pode ser falsa. "Reserva-se o termo 'conhecimento' apenas para as crenças verdadeiras” (COSTA, 1999, p. 26). Quem utiliza o método científico não conferiu nem validou experimentalmente os conhecimentos confiáveis que usa, mas os aceita com base no crédito que atribui à origem deles como resultado do método científico e da sua aceitação pela comunidade científica.

Em segundo lugar, tecemos agora considerações sobre as premissas do método científico. O método representa como que os pilares de sustentação da Ciência:

A Ciência repousa em pedra firme. A estrutura de suas teorias levanta-se, por assim dizer, num pântano. Semelha-se a um edifício construído sobre pilares. Os pilares são enterrados no pântano, mas não em qualquer base 
natural ou dada. Se deixamos de enterrar mais profundamente esses pilares, não o fazemos por termos alcançado terreno firme. Simplesmente nos detemos quando achamos que os pilares estão suficientemente assentados para sustentar a estrutura (POPPER, 1975, p. 119).

Nessa analogia dos pilares, as premissas, axiomas ou princípios do método estão numa posição mais primordial que o método em si. Não se trata de meros axiomas localizados já na construção que se ergue acima, axiomas de uma teoria ou sistema teórico como considerados por Popper (1975, p. 74-79), mas axiomas do método que sustenta o edifício no qual surgem secundariamente tais teorias ou sistemas com seus axiomas também secundários. Assim como a Teologia declara, "por exigência epistemológica, suas premissas em alto e bom som" (BOFF, 2012, p. 118), para a Ciência moderna é também acertado fazê-lo.

A primeira consideração é que as premissas do método científico não são resultados. Elas não foram obtidas como resultado do exercício do método científico.

A segunda consideração é que, embora não sejam resultados, embora não tenham sido obtidas a partir do método científico, as premissas constituem também conhecimento confiável presente em todo exercício do método científico.

A terceira consideração é que a situação epistemológica das premissas do método científico é distinta da situação epistemológica dos resultados. De um lado, os resultados: 1) devem ser obtidos, validados e comprovados; 2) encontram-se numa condição constante de falseabilidade. De outro lado, as premissas do método: 1) não são resultados do método científico; 2) sua validade é afirmada sem prova, para elas "não há demonstração cabal e lícita, dedutiva ou indutiva" (COSTA, 1999, p. 57); 3) as premissas não estão abertas à falseabilidade.

A quarta consideração é sobre o caráter de crença verdadeira das premissas do método científico. Por crença verdadeira não se trata: 1) da crença justificada, ou seja, crença nos conhecimentos confiáveis obtidos por outros cientistas, que são aprendidos pelo especialista e que o poupam da necessidade de repetir as incontáveis pesquisas anteriores; 2) tampouco se trata da "fé não científica, metafísica" 
(POPPER, 1975, p. 306), aquela crença na certeza das hipóteses imaginadas antecipadamente e que passarão pelo crivo da experimentação. Por crença verdadeira trata-se aqui de fé naquilo que, metodologicamente, ocupa posição mais primordial: nas premissas, axiomas ou princípios que também compõem conhecimentos confiáveis, mas que não estão abertos à falseabilidade, e que são assumidos em base a um ato de fé. As premissas que mostramos constituem crenças verdadeiras que sustentam o método sobre o qual se ergue a Ciência moderna, mesmo que para elas não haja demonstração cabal e lícita.

A quinta consideração diz respeito à decisão interna do sujeito que assume a objetividade de tais crenças verdadeiras. Trata-se do ato de fé (em Teologia também designado fides qua). Um ato de fé se refere à dimensão subjetiva, e designa decisão do sujeito mantida em renovação constante dentro dele. No método científico, a adoção daquelas crenças verdadeiras, que são as premissas do método, é consequência de um ato de fé (EDITORIAL, 2010, p. 315).A visão teórica de que, no método científico, a razão atua sem interferência de atos de fé, é portanto equivocada. No método científico, a razão opera só porque, anteriormente, o sujeito se dispôs num ato de fé de aceitar as premissas do método. Quem faz a reflexão pelo método científico não está numa posição puramente racional, mas executando metodológica e previamente um salto de fé. Não se trata de uma confissão religiosa, mas isso não diminui a característica de ser um ato de fé. Metodologicamente em Ciência, ato de fé e ato de raciocinar estão também imbricados. A clareza a respeito disso enriquece a compreensão da afinidade entre Teologia e Ciência, e permite dizer que a Teologia é Ciência.

\section{A Teologia na classificação das ciências}

O arcabouço teórico-prático do método científico permitiu a edificação do sólido patrimônio de conhecimento de diversas disciplinas que desenvolveram seus métodos idiossincrásicos moldados nos passos do método científico. Costuma-se agrupar as inúmeras disciplinas científicas em dois ramos básicos: 1) Ciências Formais (como a Matemática e a Estatística, que usam método racional a priori, ao 
invés do método racional e experimental $a$ posteriori). 2) Ciências Experimentais (ou reais, no sentido de "da realidade"). Este se subdivide em outros dois: 2a) Ciências da Natureza. 2-b) Ciências Humanas. Como todo conhecimento científico é interpretativo, a denominação das Ciências Humanas como Ciências Hermenêuticas "perdeu muito de sua pertinência" (GEFFRÉ, 1989, p. 6). No Brasil, a Coordenação de Aperfeiçoamento de Pessoal de Nível Superior (CAPES) organiza uma classificação pormenorizada das Áreas do Conhecimento e de Avaliação. No documento da CAPES, no início estão as Ciências Formais, seguidas até o final do documento pelas Ciências Experimentais ou reais (CAPES, 2017, p. 1-2; 2-28 respectivamente).

Na costumeira divisão das Ciências em dois ramos básicos e sub-ramos, a Teologia vem usualmente colocada no sub-ramo "2-b", das Ciências Humanas. Por parte da cena acadêmica e do Estado, houve uma mudança no olhar a esse respeito, deixando de lado o influxo do cientificismo positivista marginalizante do século XIX e parte do século XX. É assim que aparece também na classificação da CAPES, na qual a Teologia aparece incluída (CAPES, 2017, p. 23). Contudo, historicamente a inserção da Teologia na árvore de classificação das Ciências modernas não é isenta de controvérsias.

No passado a História registra período de marcada hostilidade entre ambas. Por um lado, da parte da Teologia contra a Ciência, são célebres os processos culminados no século XVII contra Giordano Bruno - queimado vivo numa fogueira em Roma- e Galileu Galilei. O núcleo mais duro dessa hostilidade à Ciência provavelmente se verificou entre o século XVIII (em torno da Revolução Francesa) e o início do século XX.

Por outro lado, da parte da Ciência moderna contra a Teologia, não poucas vezes vigora uma postura inspirada na clássica ideologia positivista, que ingenuamente julga ser possível à razão operar independentemente de qualquer fé. Tal ótica leva a excluir a Teologia de qualquer rol das Ciências, não a deixando estar 
nem sequer entre as Ciências Humanas. Uma perspectiva semelhante já se manifestava em 1770 na obra Sistema da natureza do Barão de Holbach:

As noções teológicas só parecem ter sido inventadas para desorientar a razão do homem, para confundir o seu juízo, para tornar o seu espírito falso, para subverter as suas ideias mais claras em todas as Ciências. Nas mãos dos teólogos, a lógica - ou a arte de raciocinar - não foi mais do que um jargão ininteligível, destinado a sustentar o sofisma e a mentira [...]. Inimiga nata da experiência, a Teologia, essa Ciência sobrenatural, foi um obstáculo intransponível para o avanço das Ciências naturais (HOLBACH, 2010, p. 730).

Tal visão atingiu seu ápice a partir do século XIX e se carregou de hostilidade à Teologia, com afirmações na linha desta do filósofo Friedrich Nietzsche em 1888: "quem possui sangue de teólogo no corpo, já tem, ante todas as coisas, uma atitude enviesada e desonesta. [...] O que um teólogo percebe como verdadeiro, tem que ser falso" (NIETZSCHE, 2007, p. 15-16). Ambientes marcados por semelhantes ideologias de rebeldia antiteológica sustentam que não faz sentido considerar como Ciência um ramo do conhecimento que trate sobre Deus e que faça recurso à fé e à revelação divina, pois atos de fé assinalariam, no mínimo, a infantilidade da condição humana, e provavelmente sua deturpação. Contudo, entrar nesse acirramento mútuo de ânimos impede a racionalidade.

\subsection{O estatuto científico da Teologia}

As reflexões sobre o estatuto científico da Teologia compõem um tema clássico nos estudos teológicos, abordado de vários modos (LATOURELLE, 1971, p. 47-53; PANNENBERG, 1973, p. 225-348; FRIES, 1987, p. 146-176; HERCSIK, 2004).

Um marco na consideração da questão é S. Tomás de Aquino em STh I, q.1, a.2, que a examinou com o pressuposto da noção aristotélica de Ciência, de cunho metafísico. Por um lado, Ciência (scientia) em Tomás tem o sentido de conhecimento da essência das coisas e de suas causas, elevado do campo dos acontecimentos perceptíveis pelos cinco sentidos, e alcançado o campo do ser e da essência. Por outro lado, a Teologia é referida em S. Tomás como sacra doctrina. 
Tomás manifesta-se positivamente sobre a relação entre ambas: "Respondo dizendo que a doutrina sagrada é Ciência", acrescentando na sequência: "e desse modo [... :] aceitando os princípios revelados a ela por Deus” (STh I, q.1, a.2, c).

Contudo, para a compreensão de Ciência no sentido moderno, a conclusão de Tomás não é de grande ajuda porque, embora a palavra Ciência seja idêntica, o significado do conceito passou por grande transformação. Segundo a compreensão atual, com o termo Ciência indica-se uma disciplina que possui um objeto próprio (que pode ser de ordem experimental, humana, histórica ou abstrata), um método idiossincrásico moldado no método científico, e que conduz a uma síntese comunicável e verificável pelos demais (HERCSIK, 2004, p. 52).

A Teologia, por um lado, enquanto Ciência, vale-se e beneficia-se com o sistemático caminho metodológico das Ciências modernas. A Teologia é uma disciplina que possui um objeto próprio e um método idiossincrásico moldado no método científico, que conduz a uma síntese comunicável e verificável pelos demais. A Teologia é Ciência (no sentido moderno deste termo) em determinada perspectiva. Por outro lado, o método teológico incorpora também elementos que não fazem parte do moderno método científico. A Teologia não é Ciência sob outra perspectiva. Tais parâmetros serão sistematicamente reagrupados nos dois tópicos seguintes.

Na questão do estatuto científico da Teologia provavelmente temos um caso no qual pode ser aplicada a Lógica paraconsistente ${ }^{10}$. Nos termos da Lógica paraconsistente, provavelmente são significativamente válidas as duas afirmações: a Teologia é Ciência, e a Teologia não é Ciência. Elas são contraditórias pelo sistema conceitual da Lógica clássica, a Lógica aristotélica, com seu princípio de não contradição: uma proposição não pode ser verdadeira e falsa ao mesmo tempo, sem incorrer em "colapso doxástico (acredita-se em tudo) ou trivialidade (tudo é demonstrável)" (COSTA, 1999, p. 63). A Lógica paraconsistente maneja "sistemas de

\footnotetext{
${ }^{10}$ Uma definição sucinta das diferenças entre Lógica paraconsistente e Lógica clássica (que é a Lógica aristotélica, com o princípio de não contradição) encontra-se em Costa (1999, p. 86). Um esboço histórico da Lógica paraconsistente está também em Costa (1999, p. 101-104; 289-290; 298-300).
} 
proposições que podem encerrar contradições (inconsistências), sem o perigo permanente de trivialização (de tudo ser demonstrável)" (COSTA, 1999, p. 86-87; 289).

\subsection{Algumas diferenças entre o método teológico e o científico}

\subsubsection{Confissão religiosa}

Durante o exercício da Teologia é necessária a inserção numa confissão religiosa. Isso é válido para qualquer Teologia: católica, protestante, judaica, islâmica, umbandista. $\mathrm{O}$ teólogo não está em cima do muro no que diz respeito à pertença a uma religião, ele trabalha a partir de uma perspectiva de dentro da confissão religiosa. Para o trabalho na interface entre a Teologia e as demais disciplinas científicas, mormente as Ciências da Religião, é valioso o conhecimento desta que é a mais substancial diferença epistemológica entre as duas vertentes: "reflexão 'de fora' (Ciência da Religião) e [...] reflexão 'de dentro' (Teologia)" (HOCK, 2010, p. 214).

Em Teologia e Ciências da Religião, o objeto material de estudo é semelhante: temas da religião. Por um lado, as Ciências da Religião estudam os fenômenos religiosos imanentes. Por outro lado, a Teologia afirma que eles são elementos penúltimos, suscitados pala manifestação de uma realidade transcendente. $\mathrm{O}$ foco principal dos estudos da Teologia recai sobre tal elemento último.

Apesar de o objeto material de estudo ser semelhante, o objeto formal (isto é, o ponto de vista ou perspectiva) será bem diferente. Uma coisa é estudar temas religiosos com a perspectiva da Teologia, que é confessional. É tal adesão metodológica que legitima o discurso da Teologia sobre o elemento último, aquela realidade transcendente. Outra coisa é estudar temas religiosos com a perspectiva das Ciências da Religião, que será a ótica não confessional. Metodologicamente, a Ciência moderna prescinde de Deus. "Qualquer entidade que, por definição, existe além das leis naturais, está além da esfera da Ciência” (GLEISER, 2011). Durante o 
exercício de seu trabalho, o cientista da religião colocará sua fé religiosa como que entre parênteses, sem deixar que ela interfira sobre os resultados de sua pesquisa científica. Ora, afirmações sobre igualdade ou desigualdade de valor de coisas divinamente originadas ultrapassam o limite posto pelo moderno método científico de se prescindir de Deus e, portanto, não possuem estatuto científico. Isso é relevante para o caso de estudos que adotam a teoria pluralista das religiões. Tratase de uma teoria que faz juízos sobre revelações divinas. A teoria pluralista das religiões sustenta que, de um modo geral, as diferentes revelações divinas das diversas tradições religiosas de todo o mundo têm valor semelhante. Essa é uma noção fora de qualquer confissão religiosa e, portanto, metodologicamente não é teológica. Por tematizar entidade que existe além das leis naturais, tal teoria é também não científica, incompatível com as Ciências da Religião.

\subsubsection{Conversão}

Outro elemento distintivo do método teológico é a conversão. Ela guarda uma analogia com o apreço e a valorização da ética pelo cientista. Contudo, a vida ética e honesta, embora louvável, não constitui um passo ou movimento do método científico. Ao contrário, a conversão de quem faz Teologia é um elemento próprio do método teológico e sempre incide sobre a Teologia que se produz (LONERGAN, 2012, p. 303). Conversão significa entrar numa relação de diálogo e convivência com uma realidade que não é uma coisa ou algo, mas um Alguém dialogante e reconhecido como o Santo por excelência (1Pd 1,15; Lv 19, 1-2). A entrada e perseverança na conversão coloca a pessoa no dinamismo denominado reinado de Deus (AQUINO JÚNIOR, 2010, p. 187-197). Significa inserção num determinado modo de proceder que acarreta consequências existenciais relevantes. Trata-se de uma santidade que toma prejuízo fazendo o bem (nunca o mal) aos demais. Tratase também de uma santidade de proximidade com os sofredores, os pobres e os fracos. A conversão é levada a cabo num mundo cujo modo de proceder vai em direção contrária, no dinamismo denominado antirreino, de levar vantagem em tudo e de afastar-se dos pequenos, pobres e sofredores. A inserção numa determinada direção, vivendo no mundo que vai noutra direção, faz com que a 
conversão "seja algo conflitivo e que encontre enormes resistências e oposições" (AQUINO JÚNIOR, 2010, p. 197).

\subsubsection{Não existe natureza pura}

Para o método teológico inexiste uma natureza pura, isto é, uma "natureza completa, consistente, suficiente, independente por ela mesma em relação a qualquer 'ordem' superior" (DE LUBAC, 1946, p. 174). Toda a realidade do cosmo depende em sua existência de uma ordem que está além dele, que o transcende e, nesse sentido, lhe é superior. Tal ordem superior não consiste em alguma forma de energia, nem um vasto sistema impessoal, como um princípio mecânico e neutro. Trata-se de um Alguém sem qualquer conotação mecânica, que em liberdade plena tem um viés ou inclinação que, em linguagem humana, pode ser palidamente descrito como amor gratuito e incondicional que toma prejuízo fazendo o bem (nunca o mal).

\subsection{Algumas semelhanças entre o método teológico e o científico}

\subsubsection{Ato de fé}

Neste assunto, há uma diferença atual entre Teologia e Ciência moderna. A Teologia declara, "por exigência epistemológica, suas premissas em alto e bom som" (BOFF, 2012, p. 118), ao passo que é raro encontrar a temática das premissas nos estudos de metodologia científica. Vimos aqui que, no método científico, a adoção das crenças verdadeiras, que são as premissas do método, é consequência de um ato de fé. "A Ciência é muitas vezes contrastada com a crença, mas a verdade é que a crença desempenha um papel tão grande na Ciência quanto na maioria das outras áreas da atividade humana" (LONERGAN, 2012, p. 58).

Não se trata aqui meramente: 1) da crença justificada, isto é, crença nos conhecimentos confiáveis obtidos por outros cientistas, conhecimentos que se aprendem ao longo da formação científica e que poupam a pessoa da necessidade de ter que repetir todas as incontáveis pesquisas que os geraram; 2) tampouco se 
trata daquela "fé não científica, metafísica" (POPPER, 1975, p. 306) a respeito da autenticidade das hipóteses imaginadas antecipadamente e que passarão pelo crivo da experimentação.

Antes, refere-se aqui, à fé na veracidade das premissas do método científico, para as quais "não há demonstração cabal e lícita, dedutiva ou indutiva" (COSTA, 1999, p. 57). Foram aqui mostradas oito delas. Elas também compõem conhecimentos confiáveis, e são assumidas em base a um ato de fé. Não foram obtidas como resultado do emprego do método científico, e tampouco estão abertas à falseabilidade. A clareza a esse respeito estabelece parâmetros para enriquecer a compreensão da afinidade entre Teologia e Ciência. Em ambas, o funcionamento da razão se verifica posteriormente a um ato de fé dado pelo sujeito. Em Teologia, o ato de fé metodológico se dá dentro de uma confissão religiosa. Em Ciência, ele não é feito dentro, mas fora de uma confissão religiosa. É um ato de fé nas premissas do método científico. Estas compõem princípios epistemológicos válidos, presentes em todo exercício do método científico, mas que são afirmados sem prova, sem aquela demonstração cabal e lícita, dedutiva ou indutiva.

\subsubsection{Cinco passos ou movimentos}

Os cinco passos ou movimentos do método científico que consideramos anteriormente têm cidadania no exercício da atividade teológica.

1. O ponto de partida é um assunto que precisa ser esclarecido. É indispensável ter gosto por ele. Por exemplo, em Teologia há um esquema clássico de se trabalhar um tema num autor, desde que ambos sejam relevantes. Por autor se compreende, por exemplo: um livro da Sagrada Escritura; um Padre da Igreja; um concílio; um teólogo da Escolástica ou do tempo moderno. Em tal esquema clássico, vê-se que naquele autor se encontra o importante elemento $\mathrm{X}$, que é relevante pelo motivo $\mathrm{Y}$ e que apresenta o assunto ou problema $\mathrm{Z}$ a ser esclarecido. Faz-se então a caracterização geral da questão, reunindo-se os dados relevantes. Com eles compõe-se o estado da questão. Em Teologia esse primeiro passo ou movimento é 
usualmente designado auditus fidei, a escuta da fé. É imprescindível um domínio satisfatório do patrimônio anterior de conhecimento.

2. Com o segundo passo ou movimento inicia-se o que em Teologia se chama de intellectus fidei: a reflexão sobre a fé. Quem faz Teologia formula então hipóteses sobre a questão que se propõe a esclarecer. Trata-se de uma arte, mas que, para ser praticada, requer o prévio domínio do patrimônio anterior de conhecimento. Sem este, a arte do passo 2 não é possível. No caso do esquema comum que tomamos como exemplo, de se trabalhar uma questão num autor, tratase da arte de formular alguma hipótese sobre aquela questão que se propõe a esclarecer.

3. O raciocínio sobre a fé -intellectus fidei- prossegue com a dedução de previsões a partir das hipóteses formuladas sobre a questão. Em Teologia, as previsões podem ser como aquelas de uma Ciência que trabalhe com pesquisa bibliográfica, como a História. Na pesquisa bibliográfica, os dados são coletados nos documentos e obras escritas. Nessa metodologia também se fazem previsões. Estas se dão a respeito de fontes ou documentos que ainda poderão ser encontrados. A Ciência da História não é inferior, nem deixa a desejar nesse ponto, em relação às Ciências experimentais (CLELAND, 2001). Analogamente como para a Ciência da História, na Teologia se pode prever que aquilo que se encontrará em novas fontes ou documentos ainda desconhecidos coincidirá com o que está afirmado nos documentos que já se conhece. No caso do esquema comum que tomamos como exemplo, de se trabalhar uma questão num autor, prevê-se que os documentos daquele autor que forem encontrados ou pesquisados, se falarem daquela questão dirão tal e tal coisa.

4. O intellectus fidei prossegue. Trata-se agora de comprovar a verdade da previsão, ou demonstrar que ela é falsa. Na pesquisa bibliográfica, é nos documentos e obras escritas que os dados são coletados, para em seguida serem analisados e interpretados. Se a pesquisa bibliográfica mostrar que a previsão oriunda da hipótese 
acontece, então a hipótese está no bom caminho. Contudo, se a hipótese estiver em desacordo com o que se obtém na pesquisa bibliográfica, então a hipótese é falsa.

5. Finalmente faz-se a publicação do estudo e dos resultados obtidos. O quinto passo ou movimento não é menos importante, nem opcional. O trabalho será examinado e comprovado pelos demais pesquisadores da área e, após passar por tal exame, será integrado ao patrimônio de conhecimento teológico.

\section{Conclusão}

Muitos elementos fundamentais do método teológico já estavam claros antes do advento da Ciência moderna. A chegada desta significou a instauração de um poderoso caminho para a produção de conhecimentos confiáveis. A via do moderno método científico adquiriu posição de protagonismo e configurou a atual cena científica, que expõe o método teológico a exigências de precisão e de crítica.

Mediante o delineamento dos dois métodos, deu-se particular ênfase ao tema das premissas ou axiomas do método científico. Por um lado, evidenciam-se elementos em comum entre ambos. Em primeiro lugar, nos dois métodos o funcionamento da razão acontece posteriormente a um ato de fé. No método científico, trata-se de um ato de fé na veracidade das oito premissas do método. Elas são conhecimentos confiáveis, mas para os quais não há demonstração científica. Elas tampouco estão abertas a serem declaradas falsas. Em segundo lugar, ambos os métodos podem ser esquematizados nos mesmos cinco passos ou movimentos.

Por outro lado, faz-se ver que o método teológico possui elementos que não encontram correspondência no método científico: confissão religiosa, conversão e inexistência de uma natureza pura.

$\mathrm{Na}$ atual cena científica, uma interface importante tem sido aquela entre a Teologia e as Ciências da Religião. Por um lado, as Ciências da Religião estudam os fenômenos religiosos imanentes, que a Teologia denomina elementos penúltimos, 
suscitados por uma realidade transcendente e última. Por outro lado, o foco principal dos estudos da Teologia recai sobre tal elemento último e transcendente. Do ponto de vista metodológico, o que legitima o discurso da Teologia sobre o âmbito divino é a adesão a uma confissão religiosa. O moderno método científico, com seu pressuposto da natureza pura, põe o limite de se prescindir de qualquer ordem superior às leis da natureza. Quando uma Ciência tout court se põe a elaborar discursos (como a teoria pluralista das religiões) sobre semelhança ou dessemelhança de valor de coisas que se originam de uma ordem assim superior, ela ultrapassa tal limite e produz afirmações que não possuem estatuto científico.

\section{REFERÊNCIAS}

AAAS-AMERICAN ASSOCIATION FOR THE ADVANCEMENT OF SCIENCE. Science for all Americans. Oxford: Oxford University, 1990.

ACHINSTEIN, P. (ed.). Science rules. A historical introduction to scientific methods. Baltimore: Johns Hopkins University, 2004.

AQUINO JÚNIOR, F. A Teologia como intelecção do reinado de Deus. São Paulo: Loyola, 2010.

ARMSTRONG, D. What is a law of nature? Cambridge: Cambridge University, 1999.

BAENA, G. et al. Los métodos en Teología. Bogotá: Universidad Javeriana, 2007.

BEUMER, J. Die theologische Methode. Handbuch der Dogmengeschichte. Band I, Faszikel 6. Freiburg: Herder, 1972.

BOFF, C. Teoria do método teológico. 5. ed. Petrópolis: Vozes, 2012.

BORGATTI, R. Paradigma mecanicista. São Paulo: Leopardo, 2012.

CAPES. Tabela de áreas de conhecimento/avaliação, 1-28. 2017. Disponível em:<http://www.capes.gov.br/avaliacao/instrumentos-de-apoio/tabela-de-areas-doconhecimento-avaliacao >. Acesso em: 15 mar. 2018.

CLELAND, C. Historical Science, experimental Science, and the scientific method. Geology 29, p. 987-990, 2001.

COSTA, N. C. A. da. O conhecimento científico. 2. ed. São Paulo: Discurso, 1999. 
DAWKINS, R. The selfish gene. Oxford: Oxford University, 1976.

DE LUBAC, H. Surnaturel: études historiques. Paris: Aubier-Montagne, 1946.

EDITORIAL Teologia e Ciência. Perspectiva Teológica, Belo Horizonte, v. 42, n. 118, p. 309-316, 2010.

EDITORIAL Teologia e Ciências da Religião. Perspectiva Teológica, Belo Horizonte, v. 39, n. 108, p. 159-164, 2007.

ELLACURÍA, I. El método en la Teología latinoamericana. In: ELLACURÍA, I. Escritos teológicos. San Salvador: UCA, 2000. v. 1. p. 219-234.

FEYNMAN, R. The character of physical law. London: Penguin, 1992.

FIRST LETTER OF PETER. In: BÍBLIA SAGRADA: tradução da CNBB. Brasília: CNBB, 2016.

FIRST LETTER TO THE CORINTHIANS. In: BÍBLIA SAGRADA: tradução da CNBB. Brasília: CNBB, 2016.

FRIES, H. Teología fundamental. Barcelona: Herder, 1987.

GAUCH, H. Scientific Method in brief. Cambridge: Cambridge University, 2012.

GEFFRÉ, C. Como fazer teologia hoje. São Paulo: Paulinas, 1989.

GLEISER, M. Ciência, fé e as três origens. Folha de São Paulo, feb. 20. 2011. Seção Ciência. Disponível em:<http://www1.folha.uol.com.br/fsp/ciencia/fe2002201102.htm>. Acesso em: 15 mar. 2018.

HEGENBERG, L. Etapas da investigação científica. São Paulo: EPU-EDUSP, 1976.

HELVÉTIUS, C. A. Do Espírito. In: VOLTAIRE, F.; HELVÉTIUS, C. A. Voltaire IIHelvétius. São Paulo: Nova Cultural, 1988. p. 135-290.

HENRY, J. A revolução científica e as origens da ciência moderna. Rio de Janeiro: Zahar, 1998.

HERCSIK, D. La Teologia è una "Scienza"? Riflessioni sullo statuto epistemologico della Teologia. In: APARICIO VALLS, C. et al. Sapere teologico e unità della fede. Roma: Pontificia Università Gregoriana, 2004. p. 35-54.

HOCK, K. Introdução à Ciência da Religião. São Paulo: Loyola, 2010.

HOLBACH, P. H. T. Sistema da natureza. São Paulo: Martins Fontes, 2010.

JAPIASSU, H. Como nasceu a ciência moderna. Rio de Janeiro: Imago, 2007. 
KASPER, W. Die Methoden der Dogmatik. München: Kösel, 1967.

KÖCHE, J. C. Fundamentos de metodologia científica. Petrópolis: Vozes, 2009.

LATOURELLE, R. Teologia: ciência da salvação. São Paulo: Paulinas, 1971.

LEITE, F. T. Metodologia científica. Aparecida: Ideias e Letras, 2008.

LEVITICUS. In: BÍBLIA SAGRADA: tradução da CNBB. Brasília: CNBB, 2016.

LONERGAN, B. Método em Teologia. São Paulo: É Realizações, 2012.

MEDAWAR, P. Conselho a um jovem cientista. Brasília: UNB, 1979.

NEUFELD, K. Sobrenatural. In: LATOURELLE, R.; FISICHELLA, R. (ed.). Dicionário de Teologia Fundamental. Petrópolis: Vozes, 1994. p. 909-911.

NIETZSCHE, F. O Anticristo. São Paulo: Companhia das Letras, 2007.

PANNENBERG, W. Wissenschaftstheorie und Theologie. Frankfurt: Suhrkamp, 1973.

PIE-NINOT, S. Introdução à Eclesiologia. São Paulo: Loyola, 1994.

POPPER, K. A lógica da pesquisa científica. São Paulo: Cultrix-EDUSP, 1975.

POZZO, G. Método. I. Teologia Sistemática. In: LATOURELLE, R.; FISICHELLA,R. (ed.). Dicionário de Teologia Fundamental. Petrópolis: Vozes, 1994. p. 607-619.

RAMPAZZO, L. Metodologia científica. 4. ed. São Paulo: Loyola, 2009.

STRAWSON, G. Mental reality. Cambridge: MIT, 1994.

THOMAS AQUINAS. Suma teológica: parte I, questões 1-43. São Paulo: Loyola, 2001. v. 1.

VOLPATO, G. Bases teóricas para redação científica. São Paulo: Cultura Acadêmica, 2007. 